\title{
Regulation of Type 1 lodothyronine Deiodinase in Health and Disease
}

\author{
Ronald J. Koenig
}

The major physiologic function of type 1 iodothyronine deiodinase (D1) is to produce triiodothyronine $\left(\mathrm{T}_{3}\right)$ for the plasma. D1 activity is regulated by numerous factors, perhaps the most important of which in human pathophysiology is $T_{3} . T_{3}$ induces D1 expression, contributing to the $T_{3}$ excess commonly found in hyperthyroidism. Cytokines, nutritional status, sex steroids, and other factors also regulate D1 activity, although different organs often show different responses. Numerous homeostatic mechanisms can counterbalance isolated changes in D1 expression, such as the genetically decreased expression in $\mathrm{C} 3 \mathrm{H} / \mathrm{He}$ mice. Two relatively commonly used drugs, propylthiouracil and amiodarone, inhibit D1, which can have substantial effects on circulating thyroid hormone levels. Overall, many factors interact in complex ways to establish D1 levels, contributing to the circulating concentrations of thyroxine $\left(\mathrm{T}_{4}\right)$ and $\mathrm{T}_{3}$.

\section{Introduction}

T

HE MAJOR PHYSIOLOGIC function of type 1 iodothyronine deiodinase (D1) is to produce triiodothyronine $\left(T_{3}\right)$ for the plasma. However, other sources (D2 and direct thyroidal secretion) also contribute to the circulating $\mathrm{T}_{3}$. In humans, it has not been possible to quantify the percentage of plasma $\mathrm{T}_{3}$ specifically attributable to D1. D1 is expressed primarily in the liver, kidney, thyroid and pituitary. It also is expressed at low levels in numerous other tissues, such as (in the rat) intestine, placenta, lactating mammary gland and central nervous system. In contrast to the rat, humans do not express D1 in the central nervous system.

\section{D1 Ontogeny}

D1 expression during ontogeny has been investigated in several species. Although the developmental patterns of expression have been described, the mechanisms that control expression during development remain to be elucidated. In the developing chick, hepatic D1 activity is low at embryologic day 15 (E15) and gradually increases thereafter until hatching (1-3). D1 mRNA levels did not show a consistent pattern in one study (1), so the basis for the increase in D1 activity over time is not clear. It is interesting to note that plasma $\mathrm{T}_{3}$ levels increase only modestly during the early stages of the D1 increase, probably due to a simultaneous increase in D3 and/or because of D1-catalyzed inner ring deiodination.

In the rat, liver and kidney D1 mRNA and enzyme activity are low at E19-20 but rise gradually from postnatal day
1 (P1) to P10, increasing further at adulthood (4). The pattern for intestine D1 is similar, except that expression drops dramatically after P10. Pituitary and thyroid D1 increase gradually from P12 to adulthood.

In humans, D1 ontogeny has been studied only in liver (5). Using postmortem tissues from fetuses of 20 weeks' gestation, preterm infants of 27-32 weeks' gestation and term infants who survived up to 39 weeks postnatally, D1 activity did not show a clear dependence on age. D1 activity in these postmortem samples was approximately $25 \%$ of that measured in presumably healthy adult transplant donor livers. The necessity of studying postmortem tissues from sick fetuses and infants limits the conclusions, but the relatively prominent fetal hepatic D1 activity contrasts with fetal rat liver yet is similar to ontogeny in chick liver. Also similar to the chick, human fetal serum $\mathrm{T}_{3}$ is low despite the clear expression of D1. These same human fetal livers robustly expressed D3 (in contrast to adult liver), which presumably helps prevent the accumulation of circulating $\mathrm{T}_{3}$.

\section{Regulation of $\mathrm{D} 1$ by $\mathrm{T}_{3}$}

Thyroid hormone induces transcription of the human, rat and mouse D1 (Dio1) genes $(6,7)$, although this regulation is not universal because it is absent in the house musk shrew (8). In humans, therefore, one would expect hyperthyroidism to induce $\mathrm{D} 1$, increasing relative $\mathrm{T}_{3}$ production. Indeed, hyperthyroidism is commonly associated with a greater elevation in $\mathrm{T}_{3}$ than $\mathrm{T}_{4}$, and D1 activity was elevated approximately threefold in a group of seven Graves' disease thyroid glands compared to five normal thyroids (9). Furthermore, plasma 
$\mathrm{T}_{3}$ levels appear to be decreased by the D1 inhibitor propylthiouracil (PTU) more substantially in hyperthyroid patients than in normal individuals, suggesting that D1 makes a larger contribution to circulating $\mathrm{T}_{3}$ in hyperthyroidism than in the euthyroid state (discussed in Bianco et al. [10]).

The human Dio1 promoter contains two functional $\mathrm{T}_{3}$ response elements (TREs) (11). The more distal TRE has the classic structure of an AGGTCA-like direct repeat separated by a 4-bp spacer. As expected, this TRE binds well to heterodimers of retinoid $X$ receptors (RXRs) and $T_{3}$ receptors (TRs). The proximal TRE is quite unusual and has the structure of a direct repeat separated by $10 \mathrm{bp}$. The binding sites are octamers (YYRGGTCA) rather than hexamers, and this TRE binds TR monomers and homodimers, but does not bind RXR-TR heterodimers. It is the first example of a naturally occurring TRE that appears to function independently of RXR. Although the rat and mouse Dio1 genes also are induced by $\mathrm{T}_{3}$, the TREs have yet to be identified.

There are two TR genes (Thra and Thrb), and the major functional receptors derived from these genes are denoted $\mathrm{TR} \alpha_{1}$ and $\mathrm{TR} \beta_{1}$. Liver expresses substantially more $\mathrm{TR} \beta_{1}$ than $\operatorname{TR} \alpha_{1}$. As is found for many hepatic proteins, the expression of $\mathrm{TR} \beta_{1}$ is not uniform, but is zonated. In rodents, $\mathrm{TR} \beta_{1}$ expression is highest close to the central veins, and D1 expression probably is highest in the same regions (12). $\mathrm{T}_{3}$ induction of hepatic and renal D1 is severely blunted in $\mathrm{TR} \beta_{1}$-null mice, but is normal in $\mathrm{TR} \alpha_{1}$-null mice (13). Mice that are null for both TRs have no detectable hepatic D1, demonstrating an ancillary role for $\mathrm{TR} \alpha_{1}$ in the regulation of Dio1 and indicating that $\mathrm{TRs}\left(\mathrm{TR} \beta_{1}\right.$ or $\left.\mathrm{TR} \alpha_{1}\right)$ are required for the basal expression of hepatic D1.

\section{Thyroid D1}

In addition to being induced by $\mathrm{T}_{3}$, thyroid gland $\mathrm{D} 1$ activity is induced by thyrotropin (TSH) (14-16) and cyclic adenosine monophosphate (cAMP) (17), the major mediator of TSH signaling. The rat thyroid cell line FRTL5 often is used as a model system for studying thyrocyte biology. In FRTL5 cells, TSH and $\mathrm{T}_{3}$ also increased D1 mRNA (17). Similar to the effect of TSH, immunoglobulin G from patients with Graves' disease induced D1 (18). If this effect occurs in humans with Graves' disease, it could contribute to the relatively large elevation in serum $\mathrm{T}_{3}$. The mechanism of the TSH and cAMP effect is unknown, but it does require new protein synthesis and is somewhat slower than the response to $T_{3}$, suggesting that it may be indirect. The $T_{3}$ response is a direct transcriptional effect, although as noted above, TREs have yet to be identified in the rat and mouse Dio1 genes.

\section{Effects of Drugs on D1 Activity}

Two clinically important drugs have substantial effects on D1 activity. Although propylthiouracil (PTU) is used to treat hyperthyroidism primarily because it inhibits thyroid peroxidase, at high doses PTU also inhibits D1 activity (19). Methimazole does not have a similar effect, making PTU the preferred drug in thyroid storm. PTU is thought to inhibit D1 by complexing with the D1 active site selenocysteine via an S-Se bond (20).

Administration of the antiarrhythmia drug amiodarone leads to a predictable series of changes in serum thyroid hormone levels (21). Acutely, $\mathrm{T}_{3}$ falls and reverse triiodothyronine $\left(\mathrm{rT}_{3}\right)$ rises, followed by increases in $\mathrm{T}_{4}$ and TSH. Even- tually, a new steady state is achieved in which the $\mathrm{T}_{4}$ is increased (sometimes above the assay reference range) and the $\mathrm{TSH}$ and $\mathrm{T}_{3}$ are normal. These changes are at least partially accounted for by inhibition of D1 activity (22). Despite the clear-cut in vivo inhibition of D1, it is difficult to demonstrate inhibition by adding amiodarone to in vitro enzyme assays (23). In part this may reflect technical difficulties due to the limited solubility of amiodarone. However, amiodarone derivatives do inhibit D1 activity in vitro (23), suggesting that the in vivo effects may be caused by amiodarone metabolites. Inhibition by amiodarone derivatives appears to be competitive with the substrate $T_{4}$.

\section{The Nonthyroidal IIIness Syndrome}

The nonthyroidal illness syndrome (NTIS), also known as the sick euthyroid syndrome or low $\mathrm{T}_{3}$ syndrome, is a complex whole body response to virtually any serious illness (24). Although the validity of free hormone measurements in the NTIS has been questioned (25), it is generally felt that a low circulating free $\mathrm{T}_{3}$ is the hallmark of the syndrome (26). $\mathrm{rT}_{3}$ is elevated, and the TSH and free $\mathrm{T}_{4}$ usually are normal. In more severely ill patients the TSH is subnormal, and the free $\mathrm{T}_{4}$ also can be low in extremely ill individuals. If a patient overcomes the illness, all of these changes resolve. In fact, the TSH may transiently rise above the reference range during the recovery phase. It is commonly speculated that the NTIS is an evolutionary adaptation to illness, as tissue hypothyroidism would conserve energy. However, whether the NTIS remains adaptive in the modern day era of intensive care unit medicine is unclear. Most endocrinologists do not treat the NTIS, although well-reasoned arguments for treating the most severe cases have been put forth (27). Clinical studies have failed to demonstrate a benefit to thyroid hormone therapy in the NTIS $(28,29)$, but the very small number of patients studied makes it seem unlikely that a true benefit would have been identified, especially if only certain subgroups of patients are potential responders.

Many different changes in thyroid hormone economy contribute to the NTIS. That TSH is normal in the setting of a low free $\mathrm{T}_{3}$ indicates that the hypothalamic-pituitary axis has an altered response to circulating thyroid hormone. The decrease in serum $\mathrm{T}_{3}$ primarily reflects a decrease in peripheral deiodination of $\mathrm{T}_{4}$, but as discussed below, the basis for the decreased $T_{4}$ to $T_{3}$ conversion is uncertain and is likely multifactorial.

Animals models of illness are associated with decreases in hepatic D1 (30,31). Various cytokines have been administered to humans (32) or animals (31) in an attempt to reproduce the NTIS. Although changes similar to the NTIS including a decreased serum $\mathrm{T}_{3}$ are commonly observed, the syndrome has yet to be precisely mimicked. Thus, it is felt that cytokines contribute to the NTIS but cannot fully explain it, or that the syndrome is mediated by complex cytokine combinations that have yet to be tested experimentally.

Because a decrease in hepatic D1 is clearly associated with animal models of NTIS, the effects of cytokines on hepatocyte D1 have been studied in cell culture. Using the human hepatoma cell line HepG2, tumor necrosis factor (TNF)- $\alpha$ was observed to inhibit the $\mathrm{T}_{3}$ induction of $\mathrm{D} 1$, and this was mediated by induction of NF- $\kappa \mathrm{B}$ (33). In principle, such an effect would decrease $T_{3}$ production, which would further reduce the induction of $\mathrm{D} 1$ by $\mathrm{T}_{3}$, thus setting off a down- 
ward spiral. Another study, using primary cultures of rat hepatocytes, demonstrated that interleukin (IL)-1 and IL-6 block the $\mathrm{T}_{3}$ induction of D1, and that this effect appears to be mediated by a functional deficiency in a TR coactivator protein known as steroid receptor coactivator-1 (34).

Interestingly, the effects of cytokines on pituitary D1 appear to be in the opposite direction (35). In primary cultures of rat pituitary cells, IL-1 stimulated D1 1.8-fold, and IL-6 and TNF- $\alpha$ caused similar changes but they failed to achieve statistical significance. A single injection of lipopolysaccharide into adult male rats led to a transient 1.5 -fold elevation of anterior pituitary D1, although hepatic D1 decreased as expected. If similar inductions occur in human pituitary thyrotrophs in the NTIS, this could contribute to the failure of circulating $\mathrm{TSH}$ to rise in the face of a low circulating $\mathrm{T}_{3}$ level.

Deiodinase levels also have been studied in one large series of humans with the NTIS, in which liver and skeletal muscle biopsies were obtained from more than 50 deceased patients from the intensive care unit (36). The tissue samples were obtained on average approximately 20-25 minutes after death. D2 activity was undetectable in all of the samples. D1 enzyme activity was detectable in all livers, and D3 was detectable in many liver and muscle samples (D3 was not detectable in healthy human liver or skeletal muscle). Hepatic D1 was lowest in patients who died of cardiovascular collapse, intermediate in patients who died of multiorgan failure, and highest in patients who died acutely of severe brain damage (in those patients D1 activity was stated to be similar to that in normal liver). Although only correlations can be drawn from this study, it does suggest the potential for decreased hepatic D1 as a contributing factor to the NTIS.

However, because in humans it has not been possible to determine the contributions of D1 and D2 to circulating $\mathrm{T}_{3}$, it is not possible to determine whether inhibition of D1, D2, or both is most important in the NTIS. In addition, the unexpected induction of D3 in the above study suggests that as a possible contributing factor. Further complicating the situation, there is evidence for decreased $\mathrm{T}_{4}$ uptake into tissues during human fasting (37), which is associated with thyroid hormone changes similar to those observed in the NTIS. Obviously, decreased cellular uptake of $\mathrm{T}_{4}$ also could lead to decreased $T_{3}$ production. Thus, additional research is needed to resolve the mechanism of low $\mathrm{T}_{3}$ in the NTIS, as well as to address whether the syndrome should ever be treated (and if so, how).

\section{Mammary Gland D1}

Lactation induces deiodinase expression in the mammary gland, which is speculated to contribute to milk $\mathrm{T}_{3}$ content. In the rat, D1 is expressed, but in cows and pigs, D2 is expressed. Rat mammary gland D1 mRNA contains a shortened 3' untranslated region (38), but whether this is physiologically significant is unknown. Studies in the rat indicate that suckling induces mammary gland D1 mRNA and enzyme activity through a mechanism involving $\beta$-adrenergic stimulation, and that expression is confined to alveolar epithelial cells (39). Prolactin also increased D1 enzyme activity, but mRNA levels did not change.

\section{Sex Steroid Regulation of D1}

Hepatic D1 mRNA and enzyme activity are higher in male rats than in female rats, although there are no dif- ferences in kidney D1 $(40,41)$. Castration reduced hepatic D1 in male rats and testosterone therapy overcame this reduction, both at the mRNA and enzyme activity levels (42). In one study (42) but not in another (40), ovariectomy of rats reduced liver D1 activity and this basal level was stimulated by estrogen therapy but reduced further by progesterone (42). Progesterone also blocked the estrogen induction. The mechanisms involved are unknown. More modest but qualitatively similar changes were observed in pituitary D1.

\section{Regulation of Hepatic D1 by Circadian Rhythms and Feeding Behavior}

As noted previously, $\mathrm{TR} \beta_{1}$ and D1 are preferentially expressed in the pericentral zones in rat liver. $\mathrm{TR} \beta_{1}$ expression varies in a diurnal manner, with highest expression at the beginning of the dark period (7:30 PM) and lowest expression in the middle of the light period (1:30 PM) (12). The maximum difference is modest, approximately $30 \%$ more $\mathrm{TR} \beta_{1}$ at 7:30 PM, but this might be physiologically relevant as both $\mathrm{D} 1$ and another $\mathrm{T}_{3}$-responsive hepatocyte gene, glutamine synthase, tended to show a diurnal variation in expression with peak levels at night.

Liver D1 also is regulated by feeding behavior (43). When rats are trained to have food access restricted to only 2 or 3 hours per day, they begin to anticipate food availability as evidenced by increased locomotion and water drinking. In rats maintained on such a restricted feeding schedule (feeding from 12:00 PM to 2:00 PM daily), D1 activity was low both before (8:00 $\mathrm{AM})$ and during (11:00 $\mathrm{AM})$ anticipatory activity, but increased threefold to fourfold after eating (4:00 PM). Despite this substantial change in D1 enzyme activity, D1 mRNA was constant. This is different than the well documented decrease in rat liver D1 associated with fasting in two ways. Fasting causes a decrease in D1 mRNA as well as enzyme activity. In addition, the level of D1 activity was actually lower during anticipatory activity than following a 24-hour fast in rats otherwise fed ad libitum. As an aside, it should be noted that the fasted rat is a poor model for fasting humans.

\section{D1 Deficiency}

Because the role of D1 is to supply plasma $T_{3}$, one might expect D1 deficiency to result in a low $\mathrm{T}_{3}$ concentration. There are no documented cases of D1 deficiency in humans, and D1 null animals have not been generated. However, the mouse strain $\mathrm{C} 3 \mathrm{H} / \mathrm{He}$ has 5-10 fold reduced $\mathrm{D} 1 \mathrm{ex}-$ pression relative to most other strains, such as C57BL/6 $(44,45)$. Remarkably, total and free $\mathrm{T}_{3}$ levels are normal in $\mathrm{C} 3 \mathrm{H} / \mathrm{He}$ mice. This normal free $\mathrm{T}_{3}$ is generated at the expense of twice normal circulating free $\mathrm{T}_{4}$ levels, thus illustrating the power of thyroid axis homeostasis. Perhaps surprisingly, the normal free $\mathrm{T}_{3}$ and elevated free $\mathrm{T}_{4}$ occur with no detectable change in circulating TSH. This reequilibrated state likely is a consequence of several counterbalancing forces. Assuming mice are similar to rats, then direct thyroidal secretion accounts for approximately $40 \%$ of circulating $\mathrm{T}_{3}$ (versus $20 \%$ in humans), and D1 accounts for approximately half of the remainder. While the fractional conversion of $\mathrm{T}_{4}$ to $\mathrm{T}_{3}$ by $\mathrm{D} 1$ would be reduced in $\mathrm{C} 3 \mathrm{H} / \mathrm{He}$ mice, the higher free $\mathrm{T}_{4}$ level would increase the net flux through this system. $\mathrm{D} 1$ also can degrade $\mathrm{T}_{4}$ via inner ring 
deiodination, and presumably this activity would be decreased in $\mathrm{C} 3 \mathrm{H}$ mice, helping to maintain the elevated free $\mathrm{T}_{4}$. The fact that TSH is not decreased in response to the high free $T_{4} /$ normal free $T_{3}$ state perhaps reflects decreased pituitary $\mathrm{D} 2\left(\mathrm{~T}_{4}\right.$ stimulates proteosomal degradation of $\left.\mathrm{D} 2\right)$, which would lead to reduced pituitary $\mathrm{T}_{3}$. Overall, these multiple factors enforce euthyroidism in the $\mathrm{C} 3 \mathrm{H} / \mathrm{He}$ mouse. The results suggest that partial D1 deficiency in humans, should it exist, might be well compensated and difficult to detect.

The underlying reason for decreased D1 expression in $\mathrm{C} 3 \mathrm{H} / \mathrm{He}$ mice has been carefully investigated. The enzyme itself is normal, but expression at the mRNA and protein levels is reduced. The defect maps to the Dio1 gene itself, and appears to be accounted for at least in part by a $21 \mathrm{bp}$ insertion in the promoter region that includes five CTG repeats (46). The 21-bp insertion correlates with decreased promoter activity, but the mechanism is not known.

\section{D1 Activity and Circulating Thyroid Hormone Levels in Selenium Deficiency}

Because D1 is a selenoprotein, one would predict that selenium deficiency would decrease D1 enzyme activity. In fact, selenium deficiency in rats was shown to decrease hepatic and renal D1 activity before the enzyme was cloned and demonstrated to contain selenocysteine (47-49). However, organs such as the thyroid and pituitary are much more resistant to dietary selenium deficiency than is the liver, so the effects of selenium deprivation depend on the organ being studied. Selenium deficient rats have an elevated $\mathrm{T}_{4}$, a very slightly reduced $\mathrm{T}_{3}$ and a normal TSH $(47,48)$. At least in terms of the $\mathrm{T}_{4}$ and $\mathrm{TSH}$, these findings are similar to what is observed in the partially D1-deficient $\mathrm{C} 3 \mathrm{H} / \mathrm{He}$ mouse (44). However, it should be recognized that selenium deficiency could influence thyroid hormone levels by mechanisms independent of D1. For example, selenium deficiency could impair D2 or D3 activity. In addition, even though the thyroid is relatively resistant to selenium deficiency, decreased activity of the selenoenzyme glutathione peroxidase in the thyroid might increase peroxide levels, which could enhance iodine organification in the short term or be cytotoxic in the long term.

In humans, it would be difficult to find cases of pure, isolated selenium deficiency. Nevertheless, selenium deficient humans tend to have mildly elevated serum $\mathrm{T}_{4}$ levels (50-53). Interestingly, in an area of Zaire with both iodine and selenium deficiency, selenium supplementation was associated with a decrease in serum $\mathrm{T}_{4}$ and, in subjects with cretinism, an elevation in TSH (i.e., worsening hypothyroidism) [54,55]. One possible explanation is that selenium deficiency reduced D1-catalyzed inner ring deiodination of thyroid hormones, thus protecting against hypothyroidism.

\section{D1 Activity in Diabetes Mellitus}

Experimental diabetes mellitus in rats caused a 50\%-60\% decrease in hepatic and kidney D1, as well as decreases in serum $T_{3}$ and $T_{4}(56)$. Insulin treatment resulted in a slow increase in D1 mRNA, with an increase first noted at 72 hours and normalization after 1 week. In contrast, glucagon administration appears to reduce D1 activity (57).

\section{D1 in Pituitary Tumors}

Because D1 is expressed in the normal anterior pituitary, it might be anticipated that human pituitary tumors also could express this enzyme. One study has reported the measurement of deiodinase activity in 43 pituitary adenomas and three normal pituitaries, all removed surgically (58). The adenomas included 18 nonfunctioning tumors, 7 TSH-secreting tumors, 5 growth hormone $(\mathrm{GH})$ secreting tumors, 1 combined TSH and GH-secreting tumor, 8 prolactinomas and 4 adrenocorticotropic hormone (ACTH)-secreting tumors. Although there was a large variation in D1 activity within tumor types, the highest activities were seen in the thyrotroph and lactotroph adenomas. Approximately half of these tumors had D1 activities several-fold greater than any of the three normal pituitaries. Many of the tumors also expressed D2.

\section{Summary and Conclusions}

Type 1 deiodinase activates thyroxine via outer ring deiodination and also has the ability to inactivate thyroid hormone via inner ring deiodination. Thus, D1 makes an important contribution to the maintenance of circulating thyroid hormone levels. Although the percent of plasma $\mathrm{T}_{3}$ that is caused by D1 activity has been quantified in the rat, it has been difficult to make a similar determination in humans. D1 expression is highest in the liver, kidney, thyroid and pituitary, and it also is expressed at low levels in several other organs. $\mathrm{T}_{3}$ induces D1 expression at the transcriptional level, which contributes to the relative excess of $T_{3}$ in hyperthyroidism. Amiodarone (or its metabolites) inhibits D1 activity, potentially creating difficulty in the interpretation of thyroid function tests. The ability of PTU to inhibit D1 is advantageous in the treatment of severe hyperthyroidism. D1 activity is low in the nonthyroidal illness syndrome, where this may contribute to the low $\mathrm{T}_{3}$ state. $\mathrm{D} 1$ activity in other organs, such as the lactating mammary gland, may be physiologically important, although further research is needed to better define the roles of D1 in human health and disease.

\section{Acknowledgment}

This work was supported by National Institutes of Health grant R01 DK44155.

\section{References}

1. Van der Geyten S, Sanders JP, Kaptein E, Darras VM, Kuhn ER, Leonard JL, Visser TJ 1997 Expression of chicken hepatic type I and type III iodothyronine deiodinases during embryonic development. Endocrinology 138:5144-5152.

2. Valverde RC, Aceves C, Reyes E 1993 Ontogenesis of iodothyronine deiodinase activities in brain and liver of the chick embryo. Endocrinology 132:867-872.

3. Reyns GE, Venken K, Morreale de Escobar G, Kuhn ER, Darras VM 2003 Dynamics and regulation of intracellular thyroid hormone concentrations in embryonic chicken liver, kidney, brain, and blood. Gen Comp Endocrinol 134:80-87.

4. Bates JM, St Germain DL, Galton VA 1999 Expression profiles of the three iodothyronine deiodinases, D1, D2, and D3, in the developing rat. Endocrinology 140:844-851. 
5. Richard K, Hume R, Kaptein E, Sanders JP, van Toor H, De Herder WW, den Hollander JC, Krenning EP, Visser TJ 1998 Ontogeny of iodothyronine deiodinases in human liver. I Clin Endocrinol Metab 83:2868-2874.

6. Berry MJ, Banu L, Larsen PR 1991 Type I iodothyronine deiodinase is a selenocysteine-containing enzyme. Nature 349: 438-440.

7. Berry MJ, Kates AL, Larsen PR 1990 Thyroid hormone regulates type I deiodinase messenger RNA in rat liver. Mol Endocrinol 4:743-748.

8. Rogatcheva M, Hayashi Y, Oda S, Seo H, Cua K, Refetoff S, Murakami M, Mori M, Murata Y 2002 Type 1 iodothyronine deiodinase in the house musk shrew (Suncus murinus, Insectivora: Soricidae): cloning and characterization of complementary DNA, unique tissue distribution and regulation by $\mathrm{T}_{3}$. Gen Comp Endocrinol 127:48-58.

9. Ishii $H$, Inada $M$, Tanaka $K$, Mashio $Y$, Naito $K$, Nishikawa M, Imura H 1981 Triiodothyronine generation from thyroxine in human thyroid: Enhanced conversion in Graves' thyroid tissue. J Clin Endocrinol Metab 52:1211-1217.

10. Bianco AC, Salvatore D, Gereben B, Berry MJ, Larsen PR 2002 Biochemistry, cellular and molecular biology, and physiological roles of the iodothyronine selenodeiodinases. Endocr Rev 23:38-89.

11. Toyoda N, Zavacki AM, Maia AL, Harney JW, Larsen PR 1995 A novel retinoid X receptor-independent thyroid hormone response element is present in the human type 1 deiodinase gene. Mol Cell Biol 15:5100-5112.

12. Doulabi BZ, Platvoet-ter Schiphorst $M$, van Beeren HC, Labruyere WT, Lamers WH, Fliers E, Bakker O, Wiersinga WM $2002 \mathrm{TR} \beta 1$ protein is preferentially expressed in the pericentral zone of rat liver and exhibits marked diurnal variation. Endocrinology 143:979-984.

13. Amma LL, Campos-Barros A, Wang Z, Vennstrom B, Forrest D 2001 Distinct tissue-specific roles for thyroid hormone receptors beta and alpha1 in regulation of type 1 deiodinase expression. Mol Endocrinol 15:467-475.

14. Erickson VJ, Cavalieri RR, Rosenberg LL 1982 Thyroxine-5'deiodinase of rat thyroid, but not that of liver, is dependent on thyrotropin. Endocrinology 111:434-440.

15. Ishii $H$, Inada $M$, Tanaka $K$, Mashio $Y$, Naito $K$, Nishikawa M, Matsuzuka F, Kuma K, Imura H 1983 Induction of outer and inner ring monodeiodinases in human thyroid gland by thyrotropin. J Clin Endocrinol Metab 57:500-505.

16. Wu SY 1983 Thyrotropin-mediated induction of thyroidal iodothyronine monodeiodinases in the dog. Endocrinology 112:417-424.

17. Toyoda N, Nishikawa M, Mori Y, Gondou A, Ogawa Y, Yonemoto T, Yoshimura M, Masaki H, Inada M 1992 Thyrotropin and triiodothyronine regulate iodothyronine $5^{\prime}$ deiodinase messenger ribonucleic acid levels in FRTL-5 rat thyroid cells. Endocrinology 131:389-394.

18. Toyoda N, Nishikawa M, Horimoto M, Yoshikawa N, Mori

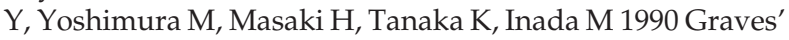
immunoglobulin $\mathrm{G}$ stimulates iodothyronine 5'-deiodinating activity in FRTL-5 rat thyroid cells. I Clin Endocrinol Metab 70:1506-1511.

19. Oppenheimer JH, Schwartz HL, Surks MI 1972 Propylthiouracil inhibits the conversion of L-thyroxine to L-triiodothyronine. An explanation of the antithyroxine effect of propylthiouracil and evidence supporting the concept that triiodothyronine is the active thyroid hormone. J Clin Invest 51:2493-2497.

20. Leonard JL, Rosenberg IN 1978 Thyroxine 5'-deiodinase activity of rat kidney: Observations on activation by thiols and inhibition by propylthiouracil. Endocrinology 103:21372144.

21. Burger A, Dinichert D, Nicod P, Jenny M, Lemarchand-Beraud T, Vallotton MB 1976 Effect of amiodarone on serum triiodothyronine, reverse triiodothyronine, thyroxin, and thyrotropin. A drug influencing peripheral metabolism of thyroid hormones. I Clin Invest 58:255-259.

22. Sogol PB, Hershman JM, Reed AW, Dillmann WH 1983 The effects of amiodarone on serum thyroid hormones and hepatic thyroxine 5 '-monodeiodination in rats. Endocrinology 113:1464-1469.

23. Ha HR, Stieger B, Grassi G, Altorfer HR, Follath F 2000 Structure-effect relationships of amiodarone analogues on the inhibition of thyroxine deiodination. Eur J Clin Pharmacol 55:807-814.

24. McIver B, Gorman CA 1997 Euthyroid sick syndrome: An overview. Thyroid 7:125-132.

25. Faber J, Siersbaek-Nielsen K 1996 Serum free 3,5,3'-triiodothyronine (T3) in non-thyroidal somatic illness, as measured by ultrafiltration and immunoextraction. Clin Chim Acta 256:115-123.

26. Chopra IJ, Taing P, Mikus L 1996 Direct determination of free triiodothyronine (T3) in undiluted serum by equilibrium dialysis/radioimmunoassay (RIA). Thyroid 6:255259.

27. DeGroot LJ 2003 "Non-thyroidal illness syndrome" is functional central hypothyroidism, and if severe, hormone replacement is appropriate in light of present knowledge. I Endocrinol Invest 26:1163-1170.

28. Becker RA, Vaughan GM, Ziegler MG, Seraile LG, Goldfarb IW, Mansour EH, McManus WF, Pruitt BA Jr, Mason AD Jr 1982 Hypermetabolic low triiodothyronine syndrome of burn injury. Crit Care Med 10:870-875.

29. Brent GA, Hershman JM 1986 Thyroxine therapy in patients with severe nonthyroidal illnesses and low serum thyroxine concentration. I Clin Endocrinol Metab 63:1-8.

30. Kahl S, Elsasser TH, Blum JW 2000 Effect of endotoxin challenge on hepatic 5'-deiodinase activity in cattle. Domest Anim Endocrinol 18:133-143.

31. Boelen A, Maas MA, Lowik CW, Platvoet MC, Wiersinga WM 1996 Induced illness in interleukin-6 (IL-6) knock-out mice: a causal role of IL- 6 in the development of the low 3,5,3'-triiodothyronine syndrome. Endocrinology 137:52505254.

32. Torpy DJ, Tsigos C, Lotsikas AJ, Defensor R, Chrousos GP, Papanicolaou DA 1998 Acute and delayed effects of a single-dose injection of interleukin-6 on thyroid function in healthy humans. Metabolism 47:1289-1293.

33. Nagaya T, Fujieda M, Otsuka G, Yang JP, Okamoto T, Seo H 2000 A potential role of activated NF-kappa B in the pathogenesis of euthyroid sick syndrome. I Clin Invest 106: 393-402.

34. Yu J, Koenig RJ 2000 Regulation of hepatocyte thyroxine 5'deiodinase by $\mathrm{T} 3$ and nuclear receptor coactivators as a model of the sick euthyroid syndrome. I Biol Chem 275:38296-38301.

35. Baur A, Bauer K, Jarry H, Kohrle J 2000 Effects of proinflammatory cytokines on anterior pituitary 5'-deiodinase type I and type II. J Endocrinol 167:505-515.

36. Peeters RP, Wouters PJ, Kaptein E, van Toor H, Visser TJ, Van den Berghe G 2003 Reduced activation and increased inactivation of thyroid hormone in tissues of critically ill patients. J Clin Endocrinol Metab 88:3202-3211. 
37. van der Heyden JTM, Docter R, van Toor $H$, Wilson JHP, Hennemann G, Krenning EP 1986 Effects of caloric deprivation on thyroid hormone tissue uptake and generation of low-T3 syndrome. Am J Physiol 251:E156-163.

38. Navarro L, Landa A, Valverde RC, Aceves C 1997 Mammary gland type I iodothyronine deiodinase is encoded by a short messenger ribonucleic acid. Endocrinology 138:4248-4254.

39. Aceves C, Pineda O, Ramirez I, de la Luz Navarro M, Valverde C 1999 Mammary type I deiodinase is dependent on the suckling stimulus: Differential role of norepinephrine and prolactin. Endocrinology 140:2948-2953.

40. Miyashita K, Murakami M, Iriuchijima T, Takeuchi T, Mori M 1995 Regulation of rat liver type 1 iodothyronine deiodinase mRNA levels by testosterone. Mol Cell Endocrinol 115:161-167.

41. Harris AR, Vagenakis AG, Braverman LE 1979 Sex-related differences in outer ring monodeiodination of thyroxine and 3,3',5'-triiodothyronine by rat liver homogenates. Endocrinology 104:645-652.

42. Lisboa PC, Curty FH, Moreira RM, Oliveira KJ, Pazos-Moura CC 2001 Sex steroids modulate rat anterior pituitary and liver iodothyronine deiodinase activities. Horm Metab Res 33:532-535.

43. Aceves C, Escobar C, Rojas-Huidobro R, Vazquez-Martinez O, Martinez-Merlos T, Aguilar-Roblero R, Diaz-Munoz M 2003 Liver $5^{\prime}$-deiodinase activity is modified in rats under restricted feeding schedules: evidence for post-translational regulation. I Endocrinol 179:91-96.

44. Berry MJ, Grieco D, Taylor BA, Maia AL, Kieffer JD, Beamer W, Glover E, Poland A, Larsen PR 1993 Physiological and genetic analyses of inbred mouse strains with a type I iodothyronine $5^{\prime}$ deiodinase deficiency. I Clin Invest 92:15171528.

45. Schoenmakers CH, Pigmans IG, Poland A, Visser TJ 1993 Impairment of the selenoenzyme type I iodothyronine deiodinase in $\mathrm{C} 3 \mathrm{H} / \mathrm{He}$ mice. Endocrinology 132:357-361.

46. Maia AL, Berry MJ, Sabbag R, Harney JW, Larsen PR 1995 Structural and functional differences in the dio1 gene in mice with inherited type 1 deiodinase deficiency. Mol Endocrinol 9:969-980.

47. Beckett GJ, Beddows SE, Morrice PC, Nicol F, Arthur JR 1987 Inhibition of hepatic deiodination of thyroxine is caused by selenium deficiency in rats. Biochem J 248:443-447.

48. Beckett GJ, MacDougall DA, Nicol F, Arthur R 1989 Inhibition of type I and type II iodothyronine deiodinase activity in rat liver, kidney and brain produced by selenium deficiency. Biochem J 259:887-892.
49. Behne D, Kyriakopoulos A, Meinhold H, Kohrle J 1990 Identification of type I iodothyronine $5^{\prime}$-deiodinase as a selenoenzyme. Biochem Biophys Res Commun 173:1143-1149.

50. Kvicala J, Zamrazil V 2003 Effect of iodine and selenium upon thyroid function. Cent Eur J Public Health 11:107-113.

51. van Bakel MM, Printzen G, Wermuth B, Wiesmann UN 2000 Antioxidant and thyroid hormone status in selenium-deficient phenylketonuric and hyperphenylalaninemic patients. Am J Clin Nutr 72:976-981.

52. Olivieri O, Girelli D, Azzini M, Stanzial AM, Russo C, Ferroni M, Corrocher R 1995 Low selenium status in the elderly influences thyroid hormones. Clin Sci (Lond) 89:637-642.

53. Calomme M, Vanderpas J, Francois B, Van Caillie-Bertrand M, Vanovervelt N, Van Hoorebeke C, Vanden Berghe D 1995 Effects of selenium supplementation on thyroid hormone metabolism in phenylketonuria subjects on a phenylalanine restricted diet. Biol Trace Elem Res 47:349-353.

54. Contempre B, Duale NL, Dumont JE, Ngo B, Diplock AT, Vanderpas J 1992 Effect of selenium supplementation on thyroid hormone metabolism in an iodine and selenium deficient population. Clin Endocrinol (Oxf) 36:579-583.

55. Contempre B, Dumont JE, Ngo B, Thilly CH, Diplock AT, Vanderpas J 1991 Effect of selenium supplementation in hypothyroid subjects of an iodine and selenium deficient area: the possible danger of indiscriminate supplementation of iodine-deficient subjects with selenium. I Clin Endocrinol Metab 73:213-215.

56. O'Mara BA, Dittrich W, Lauterio TJ, St Germain DL 1993 Pretranslational regulation of type I $5{ }^{\prime}$-deiodinase by thyroid hormones and in fasted and diabetic rats. Endocrinology 133:1715-1723.

57. Sato K, Robbins J 1981 Thyroid hormone metabolism in primary cultured rat hepatocytes. Effects of glucose, glucagon, and insulin. J Clin Invest 68:475-483.

58. Baur A, Buchfelder M, Kohrle J 2002 Expression of 5'-deiodinase enzymes in normal pituitaries and in various human pituitary adenomas. Eur J Endocrinol 147:263-268.

Address reprint requests to: Ronald J. Koenig, M.D., Ph.D. University of Michigan 5560 MSRB-2

1150 West Medical Center Drive Ann Arbor, MI 48109-0678

E-mail: rkoenig@umich.edu 


\section{This article has been cited by:}

1. P. J. Hofmann, L. Schomburg, J. Kohrle. 2009. Interference of Endocrine Disrupters with Thyroid Hormone Receptor-Dependent Transactivation. Toxicological Sciences 110:1, 125-137. [CrossRef]

2. Ibrahim Aslan, Istem Aydin, Ismet Aydin. 2009. Functional Effects of Short-Term Treatment with Amiodarone on Thyroid Tissues of the Rabbit. Biological Trace Element Research . [CrossRef]

3. Yves Debaveye , Björn Ellger, Liese Mebis, Veerle M. Darras, Greet Van den Berghe . 2008. Regulation of Tissue Iodothyronine Deiodinase Activity in a Model of Prolonged Critical IllnessRegulation of Tissue Iodothyronine Deiodinase Activity in a Model of Prolonged Critical Illness. Thyroid 18:5, 551-560. [Abstract] [PDF] [PDF Plus]

4. Stephen A Huang, Antonio C Bianco. 2008. Reawakened interest in type III iodothyronine deiodinase in critical illness and injury. Nature Clinical Practice Endocrinology \&\#38; Metabolism 4:3, 148-155. [CrossRef]

5. Gabriela Brenta, Sara Danzi, Irwin Klein. 2007. Potential therapeutic applications of thyroid hormone analogs. Nature Clinical Practice Endocrinology \&̈\#38; Metabolism 3:9, 632-640. [CrossRef]

6. Laura Vanda Papp , Jun Lu , Arne Holmgren , Kum Kum Khanna . 2007. From Selenium to Selenoproteins: Synthesis, Identity, and Their Role in Human HealthFrom Selenium to Selenoproteins: Synthesis, Identity, and Their Role in Human Health. Antioxidants \& Redox Signaling 9:7, 775-806. [Abstract] [PDF] [PDF Plus]

7. Vladislav Eybl, Dana Kotyzová, JindŘich Sýkora, OndŘej TopolČan, Richard Pikner, Martin Mihaljevič, Július Brtko, Eystein Glattre. 2007. Effects of selenium and tellurium on the activity of selenoenzymes glutathione peroxidase and Type I iodothyronine deiodinase, trace element thyroid level, and thyroid hormone status in rats. Biological Trace Element Research 117:1-3, 105-114. [CrossRef] 